\title{
Classification of Derivational and Inflectional Morphemes in Song Lyric of Ariana Grande's Album Thank U, Next
}

\author{
Euis Meinawati ${ }^{1}$, Tisha Amanda Putri ${ }^{2}$, Danang Dwi Harmoko ${ }^{3}$, Herlin Widasiwi Setianingrum ${ }^{4}$, \\ Sufi Alawiyah ${ }^{5}$
}

Universitas Bina Sarana Informatika Jakarta ${ }^{1-5}$, Indonesia

Correspondence: Euis Meinawati, Universitas Bina Sarana Informatika Jakarta; Indonesia. email: eum@bsi.ac.id

Submitted: August 29, 2020

Revised: October 14, $2020 \quad$ Accepted: August 15, 2020

DOI: $10.29408 /$ veles.v4i2.2529

URL: http://dx.doi.org/10.29408/veles. v4i2.2529

\begin{abstract}
Morphology is the study of word and sub-discipline of linguistics that study of word, structure and form which has component such as morpheme, base, prefix and suffix. This process can reduce ambiguity during the process of correcting the words in sentences. This study investigated about the classification of derivational and inflectional morphemes in the song lyrics of Ariana Grande's album Thank U, Next. This study used qualitative method. Process of collecting data used to identify lyric that has derivational and inflectional morpheme. The result of this research is to indicate that the words recorded in song lyrics can be further analyzed about the process of forming words by words and the meaning of the word in it have different meaning from the literal meaning.
\end{abstract}

Keywords: Morphology, affixations, derivational, inflectional.

\section{Introduction}

Language is needed by all human beings who live in this world, without language we cannot communicate well with people around us. Language leads us to get to know more about the meaning of language itself. As time goes by communication has finally reached the culmination of its use in conveying messages using language. Research on language by a group of people as users of the language was compiled systematically to continue usage the language until now. There is a relation in language between word and meaning because every word in the language has a meaning. Language is also concerned with linguistics because language is a formal object of linguistics. Linguistics is a study of language that is the study of structure of word-formation. Word formation has a significant meaning in language. A sub-discipline of linguistics that studies words, structure, forms, and classes of words is called morphology.

Morphology is the mental system involved in word formation or branches of linguistics that related in words, internal structure, and how the word is formed (Aronoff \& Fudeman, 2011). It 
means that morphology is a branch of linguistics that studies structure and word-formation. Meanwhile, morphology is the study of how words are constructed from units of meaning. It studies the way in which shape changes reflect different meanings (Hamawand, 2011). Words reflect the sentence and are formed by combining the word. The sentence itself can be separated into the minimum unit and meaningful part. Morpheme is the smallest meaningful unit in the language system. Morpheme is the form of unit from the most basic linguistics of the grammatical function (Fromkin, Rodman, \& Hyams, 2013). A morpheme can represented by one single word, such as the morpheme a- meaning 'Without' as in alive and alight or by a single syllable, such as boy and ish in boy $+i s h$. Every word in every language consists of one or more morphemes. Morphemes that cannot stand alone are called bound morphemes. Bound morphemes must be attached to free morphemes. Bound morphemes are also called affixes and bound morphemes can be classified into prefix, infix, and suffix. English only has two kinds of bound morphemes named prefixes and suffixes. There are no infixes in English. Prefix placed in the beginning of root word and modify the word also change the meaning itself. Meaning such as re, un, dis, re, un". A suffix is an affix placed after the root word (or stem or base) likely, -er, or, -ist, -s, -ing and -ed. For example: kind-ly, wait-er, book-s, walk-ed.

In morpheme, there are derivational and inflectional morphemes. Derivational usually changes the word class from basic lexemes (Haspelmath \& Sims, 2013). Derivation change the word class and to produce a new word. Derivational morpheme is a bound morpheme that changes the word class. It can be found in each text or narration like a song (Meinawati, Chodidjah, Alawiyah, \& Putri, 2020). The bound morpheme likely is called derivational morpheme. Derivational morpheme is the morpheme which produces a new lexeme from a base while Inflectional morpheme does not change the root class. Derivational and inflectional morphemes can give so many grammatical information about the meaning of words which they are attached to. Inflection is grammatical processes that produce alternative forms of the same lexeme. Unlike the fields that produce different words, the inflection area produces various forms of the same lexeme (Hamawand, 2011). Infection is a modification of the form of words through the addition of the root word and grammatical functions. For example, the word "friends" contained in the lyric of the song for example, the word "dreams" contained in the lyrics of the song Thank $u$, next by Ariana Grande has a meaning that does not change the word class. It is because the world is included into Inflectional Morphemes that does not change the category. Additional -s only describe as a plural form before the word "friend", if it is not coupled suffix $-\mathrm{s}$ the friend means singular. Friend is a noun.

There are many derivational and inflectional morphemes that have been discussed in previous researches. The form of affixation in song lyrics and the main focus of the research is to find out how the affixation process contained in the script song lyrics titled "Hall of Fame" (Meinawati \& Alawiyah, 2018). Aprianti \& Parmawati (2020) concerned with the morphological of linguistics analysis of inflectional and derivational used in Lady Gaga's album song lyrics entitled "A Stars is Born". Another song has the pattern of derivational and inflectional. The writer found the use of suffixes and prefixes which has their own functions in the sentence 
(Yastanti \& Warlina, 2018). The same analysis is derivational and inflectional morphemes of one direction's Up All Night Album (Agustinah, 2013). It is not only in song lyric, derivational or inflectional pattern is done in newspaper (Maulidina, Indriyani, \& Mardewi, 2019). The story has the same pattern of morphology (Kusumawardhani, 2020)

The previous research, most of them are investigated about derivation affixes. The different of this research with the previous researchers is because most of the studies are most about derivational affixes, but the writer is to focus not only about derivational affixes but also inflectional affixes that is investigate in English affixes and process the word forming and structure of words or known as word formation in the song lyrics itself.

This title is chosen from Ariana Grande album Thank U, Next as the object of research, because the writer found many words that contain affixes and the writer interested in analyzing. It makes easy for writer to find research data and there are many unique words, so the writer thinks that the words can add to the reader's knowledge and additional vocabulary. Therefore, this research aims to describe the actual derivational and inflectional morpheme in the song lyrics of Ariana Grande.

\section{Method}

This paper uses a descriptive qualitative method. Qualitative research used to analyze the phenomenon happened (Ary, 2010). qualitative research are steps that are used to collect data by researcher usually use interview, observation, questionnaire, test and documentation. The writer collects some data from lyric songs in Ariana Grande's Album Thank $u$ Next. Thank U, Next album consist of 12 songs and sung all by Ariana Grande. But the writer chose 2 songs of the total songs in the album because from 2 songs the writer found various derivational and inflectional morpheme. The research was to search for some information from books and the internet to help in analyzing the process. The analysis of this research starts from reading and understanding the theory of the formation of English words from journal articles and theoretical books. The next step is to read the lyrics contained in Ariana Grande's Album to determine the article to be analyzed. Next, identify and classify words that contain inflection and derivation, break them down into small units to find out the process in words, and also check new meanings using a dictionary. After the relevant data is obtained, inventory them into the observation table to conclude which word formations are the most widely used in the lyrics that have been analyzed from Ariana Grande's Album.

\section{Results and Discussion}

The object data of this research is about song lyric of Ariana Grande's album Thank $U$, Next. This album is the fifth studio album by American singer Ariana Grande released on February 8, 2019, by Republic Record. Thank $U$, Next album consist of 12 songs and sung all by Ariana Grande. But the writer chose 2 songs of the total songs in the album because from 2 songs the writer found various derivational and inflectional morpheme there. The title of the songs is In my head, and 7 rings. 


\subsection{Derivational morphemes in song lyrics of Ariana Grande's album}

\section{A. The song entitled 'In my head'}

Datum 1

Line 2

You're in love with a version of a person

The word version line 2 contains two morpheme, base word verse and bond morpheme suffix (-ion). The word verse as (noun) and -ion as suffix, the word version is also (noun). In this case even it does not change the syntactical category but still be categorize as derivational morphemes.

\section{Datum 2}

Line 16 My imagination's too creative

The word imagination in line 16 consist of three morphemes, base word image (noun) added by 2 bound morpheme -ina and -ion as suffix which change the syntactical category. From the base word image (noun) added by suffix -ina and it is become imagine (verb).

Datum 3

Line 19 Without a halo, wingless angel

The word wingless line 19 indicated as derivational affixes. The word wingless comes from the base word wing (noun), and it is added by suffix -less. The word wing + -less indicated as adjective, it changes the syntactical category from the base.

\section{Datum 4}

Line 16 My imagination's too creative

In line 16 found derivational suffix with in word creative, and by added suffix -ive come from the base word create (verb) The word create + -ive is classified into derivational word and changed the syntactical category from verb to adjective.

\section{Datum 5}

Line 36 I saw your potential without seeing credentials

The word potential in line 36 contain suffix. The word potential come from the base word potency (noun), and it is added by suffix -al and formed a new word become potential (adjective) by changing the ending word from $y$ to $i$.

\section{B. The song entitled '7 Rings'}

Datum 1

Line 14 Bought matching diamonds for sick of my bitches

The word matching in line 14 contains suffix -ing. Based on Oxford dictionary the word matching indicated as adjective. The word matching come from the base word match (verb) + suffix -ing. In this case the word matching as adjective change the word class a d indicated as derivational morpheme.

\section{Datum 2}

Line 15 I'd rather spoil all my friends with my riches 
In line 15 the word riches contain suffix -es. The word riches come from the base word rich (adjective). The word rich + -es become noun. It is indicated as derivational morpheme because change the syntactical category from the base word from adjective to noun.

Datum 3

Line 9 My wrist, stop watchin', my neck is flossy

In line 9 shows the word contains suffix; flossy. The word flossy constructs by two morphemes; free morpheme floss (noun) attached by bound morpheme $-y$ (nominal suffix) and become adjective and change the syntactical category and the meaning.

Datum 4

Line 20 Happiness is the same price as red bottoms

The changing of the word in line 20 happiness belong to derivational affixes, which derived from the base word happy (adjective) + suffix -ness to form a new word happiness (noun). From here that the stem happy has altered the orthographic to the base by changing the last sound from $y$ to $i$ (happiness).

Datum 5

Line 31 Black card is my business card

The changing of word in line 31 business belong to derivational affixes, which derived from the base word busy (adjective) + noun suffix -ness. We can see that the stem busy has altered the orthographic to the base by changing the last sound $y$ to $i$ (business). The word business is also change the syntactical category of the base and meaning.

\section{Datum 6}

\section{Line 16 Think retail therapy my new addiction}

The word addiction in line 16 consist of two morphemes; base word addict (noun) and bound morpheme suffix -ion to form new word addiction (noun). This not changes the syntactical category, but in this case it still indicated as derivational affixes.

\subsection{Inflectional Morphemes in Song Lyrics of Ariana Grande's Album}

\section{A. The Song Entitled 'In my head'}

\section{Datum 1}

Line 8

I'm two blocks away, I'm coming over

The word coming in data line 8 come from the case word come (verb), and it is added y suffix -ing. The word come + -ing is indicated as present participle, which not change the syntactical category from the base word before or after the affixation.

Datum 2

Line 11 I got a habit of seeing what isn't there

The word seeing in line 11 come from the base word see (verb) and added by suffix -ing. The word see + -ing as present participle which not change the syntactical category from the base word before or after the affixation. 


\section{Datum 3}

\section{Line 20 Falling, falling}

The word falling in line 20 contains suffix. Falling come from the base word fall (verb) and added by suffix -ing as progressive maker and indicated as inflectional affixes.

Datum 4

Line 28 Your Gucci tennis shoes running from your issues

The word running in line 27 indicated as inflectional affixes. The word running come from the base word run (verb), and it is added by suffix -ing as present participle.

\section{Datum 5}

Line 33 I know you are able, willing and able

The word willing come from the base word will (verb), it added by suffix -ing as present participle or progressive maker which not change the syntactical category from the base word before or after the affixation.

\section{Datum 6}

\section{Line 34 Wanted to grow, but, boy, you wasn't budding}

The word budding based on Oxford dictionary as adjective. The word bud can be as a noun or verb. In this case the word bud is a (verb), and it is added by suffix -ing as present participle and indicated as inflectional affixes.

\section{Datum 7}

Line 8 I'm two blocks away, I'm coming over

The word blocks in line 8 come from base word block (noun), and it is added by suffix (-s). The word block + -s is indicates as plural noun ending and indicated as inflectional affixes.

\section{Datum 8}

\section{Line 13 Tangled up in your sheets}

The word sheets contain suffix and come from the base word sheet (noun), and it is added by $-s$. The word sheet $+-s$ indicated as plural noun ending indicated as inflectional affixes which means more than one sheets.

\section{Datum 9}

\section{Line 28 Your Gucci tennis shoes running from your issues}

The word shoes in line 28 contain suffix -s come from the base word shoe (noun), by added suffix $-s$ indicated as plural noun ending indicated as inflectional affixes.

\section{Datum 10}

\section{Line 28 Your Gucci tennis shoes running from your issues}

The word issues in line 28 contain suffix -es. Based on Oxford dictionary the base word issue can be as a noun or a verb depend on the context itself. In this case the word issues as a noun by added suffix -es as plural noun ending. 


\section{Datum 11}

Line 3 That you're created in your head

The word created in datum line 3 is indicated as inflectional affixes since the base word is create (verb) added by suffix -ed as past tense marker indicated as inflectional affixes.

Datum 12

Line 9 Painted a picture

The word painted in line 9 indicated as inflectional morpheme it is because the base paint (verb) added by suffix (-ed) as past tense maker.

\section{Datum 13}

Line 13 Tangled up in your sheets

The word tangled in line 13 is indicated as inflectional affixes. In this sentence the word tangled as a verb, and it is added by suffix -ed. The word tangle + -ed and indicated as past tense marker.

Datum 14

Line 15 I said you only wanted half of me

The word wanted in line 15 based on Oxford dictionary as adjective, come from the base want (verb) added by suffix (-ed). But in this case the word went +-ed indicated as past tense marker and indicated as inflectional affixes.

\section{Datum 15}

Line 23 Needed something to believe in, oh

The word needed in line 23 indicated as inflectional affixes, the base word need as a verb added by suffix - $e d$ as past tense marker and does not change the syntactical category from the base.

Datum 16

Line 27 Yeah, look at you, boy, I invented you

The base word of invented come from the word invent (verb), and added by suffix -ed. The word invent + -ed indicated as past tense marker and indicated as inflectional affixes.

\section{B. The song entitled '7 Rings'}

Datum 1

Line $2 \quad$ Girls with tattoos who like getting' in trouble

The word getting come from the base word get (verb), and it is added by suffix -ing. The word get + ing as present participle and does not change the syntactical category from the base.

Datum 2

Line 9 My wrist, stop watchin', my neck is flossy 
The word watching in line 9 contain suffix and indicated as inflectional affix. The word watching come from the base word watch (verb), and it is added by suffix -ing as present participle.

Datum 3

Line 10

Make big deposits, my gloss is poppin'

The word popping in line 10 contain suffix -ing and indicated as inflectional affixes. The word popping come from the base word pop (verb), by addid suffix -ing as present participle.

Datum 4

Line 13 Wearing a ring, but ain't gon' be no "Mrs".

The word wearing come from the base word wear (verb), and it is added by suffix -ing. In this case the word wearing as present participle and indicated as inflectional morpheme.

\section{Data 5}

Line 21 My slime is beamin', my skin is gleamin'

In data line 21 there are words beaming and gleaming that indicated as inflectional affixes. The word beaming and gleaming are contain suffix -ing and come from the base word beam (verb) and gleam (verb), and by added suffix -ing as present participle.

\section{Datum 5}

Line 29 Yeah, my receipts, be lookin' like phone numbers

The word looking in line 29 indicated as inflectional affixes which contain suffix after the base word. The word looking come from the base word look (verb) and by added suffix -ing as progressive maker. Because looking refers to the word be.

\section{Datum 6}

Line 32 The way it be settin' the tone for me

The word setting in line 32 contains suffix. The word setting come from the base word set (verb), and it is added by suffix -ing as present participle. Because the word setting refers to the word be.

\section{Datum 7}

Line 1 Yeah, Breakfast at Tiffany's and bottles of bubbles

The words bottles and bubbles in data 31 line 1 both of them are contain suffix $-s$. The word bottles in line 1 contains suffix which come from the base word bottle (noun), by added suffix $-s$ as plural noun ending and indicated as inflectional affixes. The word bubbles in line 1 indicated as inflectional affixes. The word bubbles come from the base word bubble (noun) as plural noun ending.

Datum 8

Line $2 \quad$ Girls with tattoos who like getting' in trouble

The word girls indicated as inflectional affixes. The word girls come from the base word girl (noun), by adding suffix $-s$ as plural noun ending. Girls refers to more than one girl. The 
word tattoos in line 2 indicates as inflectional affixes which came from the base word tattoo (noun) and it is added by suffix $-s$ as plural noun ending and they still noun before or after affixation.

\section{Datum 9}

Line 3

\section{Lashes and diamonds, ATM machines}

The word diamonds indicated as inflectional affixes and contains suffix $-s$. The word diamonds come from the base word diamond (noun), by added suffix $-s$ as plural noun ending. The word machines contain suffix $-s$ which come from the base word machine (noun), and it is added by suffix $-s$ as plural noun ending and indicated as inflectional affixes.

\section{Datum 9}

Line 4 Buy myself all of my favorite things (yeah)

The word things contain suffix $-s$ and indicated as inflectional affixes. The word things come from the base word thing (noun), and it is added by suffix $-s$ as plural noun ending.

Datum 10

Line 7

Rather be tied up with cuffs and no strings

The word cuffs in line 7 indicated as inflectional affixes and contain suffix $-s$ after the base word. The word cuff can be indicated as a verb and a noun depend on the sentence itself. In this case the word cuff as a noun, and it is added by suffix $-s$ as plural noun ending. The word strings in line 7 contain suffix which come from the base word string (noun), and it is added by suffix $-s$ as plural noun ending, does not change the syntactical category they are still noun.

\section{Datum 11}

Line $8 \quad$ Write my own checks like I write what I sing, yeah (yeah)

The word checks in line 8 contain suffix and indicated as inflectional affixes, which not change the syntactical category from the base. In this case, the word check as noun, and it is added by suffix $-s$ as plural noun ending.

\section{Datum 12}

Line 10 Make big deposits, my gloss is poppin'

In line 10 shows the word deposits contains suffix $-s$ and as inflectional affixes; deposits, which come from the base word deposit (noun), and by added suffix $-s$ as plural noun ending.

\section{Datum 13}

Line 11 You like my hear? Gee, thanks, just bought it

In line 11 shows the word contain suffix; thanks. It is indicated as inflectional affixes which come from the base word thank (noun), and it is added by suffix $-s$ as plural noun ending.

Datum 14

Line 15 I'd rather spoil all my friends with my riches 
In line 15 we can find the word friends contain suffix and indicated as inflectional affixes. The word friends come from the base word friend (noun), and it is added by suffix $-s$ as plural noun ending.

\section{Datum 15}

Line 17 Whoever said money can't solve your problems

The word problems in line 17 contains suffix which come from the base word problem (noun), and it is added by suffix $-s$ as plural noun ending and indicated as inflectional affixes.

\section{Datum 16}

Line 29 Yeah, my receipts, be lookin' like phone numbers

The word receipts in line 29 contains suffix $-s$ which come from the base word receipt (noun), and it is added by suffix $-s$ as plural noun ending. The word numbers is contains suffix $-s$ and belong to inflectional affixes which come from the base word number (noun), and it is added by suffix $-s$ as plural noun ending.

Datum 17

Line 34 When you see them racks, they stacked up like my ass, yeah

In line 34 there is the word racks contains suffix $-s$. The word racks can be as verb or noun, but in this case the word racks indicated as a (noun), as plural noun ending.

\section{Datum 18}

Line 20 Happiness is the same price as red bottoms

The word bottoms in line 20 contains suffix and indicated as inflectional affixes. The word bottoms come from the base word bottom (noun), and it is added by suffix $-s$ as plural noun ending.

Datum 19

Line 3 Lashes and diamonds, ATM machines

The word lashes in line 3 contain suffix -es, the word lash as a noun and added by suffix -es as plural noun ending. It is indicated as inflectional affixes which does not change the syntactical category from the base.

\section{Datum 20}

\section{Line 14 Bought matching diamonds for sick of my bitches}

The word bitches in line 14 indicated as inflectional affixed and contain suffix -es. In this case the word bitch indicated as a (noun), and it is added by suffix -es as plural noun ending.

Datum 21

Line 34 When you see them racks, they stacked up like my ass, yeah

The word stacked in line 34 contains suffix -ed and indicated as inflectional affixes which come from free morpheme stack (verb), and it is added by suffix $-s$ as past tense marker.

Datum 22

Line $7 \quad$ Rather be tied up with cuffs and no strings 
The word tied in line 7 contain suffix and indicated as inflectional affixes. The word tied come from the base word tie (verb), and it is added by suffix $-d$ indicated as past tense marker.

\section{Discussion}

Based on the data analysis, there are 5 words on the song lyrics in my head' that indicated as derivational morpheme. They are the words version, imagination, wingless, creative, potential. In the song lyrics ' 7 rings' that indicated 6 words as derivational morpheme. They are the words matching, riches, flossy, happiness, business, addiction. There are 16 words on the song lyrics 'in my head' that indicated as inflectional morpheme. They are the words coming, seeing, falling, running, willing, budding, blocks, sheets, shoes, issues, created, painted, tangled, wanted, needed, invented and there are 30 words on the song lyrics in my head' that indicated as inflectional morpheme. They are the words getting, watching, wearing, popping, beaming, gleaming, looking, setting, bottles, bubbles, girls, tattoos, diamonds, machines, things, cuffs, strings, checks, deposits, thanks, friends, problems, receipts, numbers, racks, bottoms, lashes, bitches, stacked, tied.

In linguistics, derivation changes the word class and also changes the meaning of the word itself by adding prefix or suffix. For example, eauty is noun by adding ful at the end of the word beautiful the word class is changed from noun to adjective. The word-formation usually fields which produce different words but the inflectional area produces various forms of the same lexeme. It means that inflectional morpheme does not change the class of words and still have the same meaning. For example how, shows, showed, showing although they have different lexeme but they have the same meaning. In which by adding suffix $-s$ as a grammatical function of plurality, by adding suffix -ed it is as a grammatical function of past tense and by adding -ing it as a grammatical function of progressive. English has so many inflectional endings such as plural in cats, possessive in cat's, comparative in longer, superlative in longest, present in talk, past in talked, past participle in sung, present participle in singing and adverb in quickly. Inflection is not used to build a new word in the language, but to shows aspects of the grammatical function of a word. Inflection morpheme is used to indicate whether a word is plural or singular, whether it is past or present, and whether it is a comparative or possessive form (Yule, 2016).

The process of understanding morphological theories such as derivational and inflectional theories is still difficult for students. It causes about the ambiguity of meaning (Yastanti \& Setiawati, 2018). This difficulties is because word formation and meaning changes will occur when the word has been formed. So, media that can help understand the concept of derivational and inflectional can use songs, online texts, newspapers or student essays (Kusumawardhani, 2018). Many studies have been conducted in studying derivational and inflectional. Tariq et al. (2020) found some basic function of derivational and inflectional English morphemes and their negative meaning, including as noun, as adjective, as verb, as adverb, plural mark, comparative, and superlative, present perfect form, past form, present participle and past participle. 
In learning English words, it is very important to know the smallest unit that plays a role in determining a new word or meaning, called 'morpheme'. There are two types of morphemes that form new words and new meanings: derived morphemes and inflected morphemes. There are several criteria that differentiate between derivational and inflected morphemes. First, derived affixes largely change the category and/or meaning of the form to which they are applied. Second, the derived morpheme can occur inside derivation and the position of the derivation morpheme is closer to the root than the inflected morpheme, but the inflected morpheme can occur after or outside the derivation. Third, the decline is often limited in productivity; It derived morphemes can be combined with only certain words in a category change. However, inflation is fully productive, certain inflected suffixes can be combined with words of the same category. Fourth, derivation is not syntactically relevant; it's irrelevant for sentence building. In contrast, inflections are syntactically relevant. Fifth, derivation is not limited to suffixation. In contrast, inflection is always suffixional and there are no inflection prefixes in English. Finally, derivations are often semantically opaque. In contrast, inflections rarely appear semantically vague - the meaning of the words attached by the suffix can be deduced from the root (Yusuf, 2017).

\section{Conclusions}

This research generates theory-based learning in a qualitative study. It is inferred that the integrating of strategies in second language teaching and learning enables the learning process to become more complex, productive, and collaborative in terms of input of mechanical information. The use of learning strategies helps learners to be critically coordinated their academic work in a more organized, cohesive, and prepared way to get more output of the study time. Besides, learning strategies socialization that is given by the instructor may have a beneficial impact on the learners. The advantages of appropriate learning approaches would be the forum for learners to gain a deeper understanding such as an opportunity to be educated as potential teachers adequately and intelligently. The researchers concluded for further studies instead of describing the learning strategies classification and investigate learners' learning strategies appropriately. Besides, the effective measurements and answering of SILL must be implemented in EFL learning by considering several factors; students' feelings, learning atmosphere, and teachers' guidance. Finally, teachers must stimulate each learner to implement their appropriate learning strategies simultaneously, explicitly, and regularly inside or outside the classroom.

\section{References}

A. Gani, S., Fajrina, D., \& Hanifa, R. (2015). Students' Learning Strategies for Developing Speaking Ability. Studies in English Language and Education, 2(1), 16. https://doi.org/10.24815/siele.v2i1.2232

Ahmed, A., \& Abdulla, M. (2014). The Role of Language Learning Strategies ( LLS ) and the Effect of Different Individuals in Learning Target or Second Language. International Journal of Language and Linguistics, 2(3), 197-202. 
https://doi.org/10.11648/j.ijll.20140203.19

Amir, M. (2018). Language Learning Strategies Used by Junior High School EFL Learners. Language and Language Teaching Journal, 21(1), 94-103. https://doi.org/doi.org/10.24071/11t.2018.210110

Aprianto, D., \& Zaini, N. (2019). The Principles of Language Learning and Teaching in Communication Skills Developments. VELES Voices of English Language Education Society, 3(1), 45-61. https://doi.org/10.29408/veles.v3i1.1281

Aunurrahman, Kurniawati, T., \& Ramadhiyanti, Y. (2013). Exploring Indonesian College Students Strategies in Learning English Language. Arab World English Journal, 4(3), 317330. Retrieved from www.awej.org

Brown, H. D. (2000). Principles of Language Learning and Teaching (Fifth; F. E. Team, ed.). White Plains: Pearson Education.

Bulan, A., Suryaman, M., \& Mardiah, M. (2020). The Process of English Language Teaching in the 2013 Curriculum. VELES Voices of English Language Education Society, 4(1), 85-93. https://doi.org/10.29408/veles.v4i1.2007

Hou, Y. (2018). A Study of the Role of Strategy in Foreign Language Learning. Scientific Research Publishing, (8), 151-175. https://doi.org/10.4236/ojml.2018.85016

Kumaravadivelu, B. (2008). Understanding Language Teaching: From Method to Post method. The Reading Matrix, 8(1), 0-3. https://doi.org/10.4324/9781410615725

Oxford, R. (1990). Language learning Strategies: What Every Teacher Should Know. New York: Newbury House Publishers.

Oxford, R. L. (1996). Language Learning Strategy Around the World: Cross-Cultural Perspective. Manoa: Second Language Teaching and Curriculum Center.

Prasetyaningrum, A., Fikni, Z., \& Wati, L. (2020). English Foreign Language Students' Strategies in Overcoming Speaking Problems. VELES Voices of English Language Education Society, 4(1), 94-103. https://doi.org/10.29408/veles.v4i1.1914

Rose, H. (2012). Language Learning Strategy Research : Where Do We Go From Here ? Studies in Self-Access Learning Journal Language learning strategy research: Where do we go from here? Trinity College Dublin, Ireland. Studies in Self-Access Learning Journal, 3(2), 137-148. Retrieved from http://sisaljournal.org/archives/jun12/rose

Rubin, J. (1981). Uas smstr 1 fix (sept-des 2018)(1). Applied Linguistics, 2(2), 117-131. https://doi.org/10.1093/applin/II.2.117

Rubin, J., \& Thompson, I. (1982). How to be a More Successful Language Learner. Boston: Heinle \& Heinle.

Rustam, N. S., Hamra, A., \& Weda, S. (1990). The Language Learning Strategies Used by Students of Merchant Marine Studies Polytechnics Makassar. 77-94.

Salahshour, F., Sharifi, M., \& Salahshour, N. (2013). The Relationship between Language Learning Strategy Use, Language Proficiency Level, and Learner Gender. Procedia - Social and Behavioral Sciences, 70(1957), 634-643. https://doi.org/10.1016/j.sbspro.2013.01.103

Setiyadi, A. B., Sukirlan, M., \& Mahpul. (2016). How Successful Learners Employ Learning 
Strategies in an EFL Setting in the Indonesian Context. English Language Teaching, 9(8), 28-38. https://doi.org/10.5539/elt.v9n8p28

Tanjung, F. Z. (2018). Language Learning Strategies in English as a Foreign Language Classroom in Indonesian Higher Education Context. LLT Journal, 21(June), 50-68. https://doi.org/doi.org/10.24071/1lt.2018.Suppl2106

Wael, A., Asnur, M. N. A., \& Ibrahim, I. (2018). Exploring Students' Learning Strategies in Speaking Performance. International Journal of Language Education, 2(1), 65. https://doi.org/10.26858/ijole.v2i1.5238 